\title{
Genetic Criticism and the Papyri: Some Suggestions
}

\author{
Raffaella Cribiore
}

The term genetic criticism was coined in 1979 in France. Genesis is a theoretical discipline that is interested in the process of writing and approaches literary texts not as finished works but as fluid products. ${ }^{1}$ Genetic critics explore rare book and manuscript libraries and search for autograph manuscripts and for other written traces that authors have left such as notes, drafts, and alternate versions. So for example, scholars interested in some great nineteenth century French writers have formed genetic dossiers that embrace all the types of writing they left. The origin of a text that first lived in the mind of an author is inaccessible now but the whole process of reconstruction enriches the text per se. A difficulty in applying genetic criticism to antiquity is that ancient authors did not leave much written material besides the texts that we have even though, as I will mention at the end of this paper, alternate versions of passages of a few authors are extant and so far they have not attracted much attention as a corpus.

Some excellent work was recently done to elucidate revision in literary Greek and Roman texts by studying references to revision that several authors made. ${ }^{2}$ This indirect evidence to authorial revision is very important in showing how authors revised their text, sometimes in a circle of friends, but it is only in the papyri that one can witness the dynamics of the process of writing. In examining some Greek papyri, I will draw attention to aspects that are often overlooked. By concentrating on what might appear as minor features of a text, it is possible to gain insight on the behavior and motivations of some ancient writers. Taking a second look at texts is often useful. Though the text itself may remain unchallenged, its interpretation is enhanced. I will consider a Homeric papyrus with annotations by a second hand and the dossiers of the grammarian Lollianos and Ammon of Panopolis. I will also look at features in the Vatican papyrus of

\footnotetext{
${ }^{1}$ The main journal of the movements is "Genesis", the house journal of the Institut des Textes et Manuscrits Modernes (ITEM), which continues to publish theoretical and more specific articles. In this respect fundamental articles for the theorization of genetic criticism are Hay, Critique, and Neefs, Prévision. Literature in English is scarcer. The best book on the subject is Bryant, Fluid Text.

${ }^{2}$ See Gurd, Work; Martelli, Ovid; see also the forthcoming entry of S. Gurd for the OCD "Revision in Greek and Roman Literature."
} 
On Exile to try to understand the confused behavior of its scribe and to consider its graphic presentation. This will lead me to the papyrus of the Anonymus Londinensis, an isagogic text on medicine and on the causes of disease. I will draw attention to two drafts of a passage and try to show some comparanda.

\section{A Papyrus of Homer with marginalia}

An Oxyrhynchus papyrus of the early third century AD containing book V of the Iliad, P.Oxy. II 223, has often been studied and reproduced because of its main magnificent hand, in a sloping 'Severe style' ${ }^{3}$ The text was written on the verso of the 'Petition of Dionysia'. It was donated to the Bodleian Library many decades ago and the only photos readily available are old scans in black and white. The papyrus contains a great amount of lectional signs that, contrary to the opinion of the editors, appear to me done by the first hand. The editors called the second hand "rough and uncultivated" but it is clear that the writer was not a beginner, wrote speedily, and somewhat cursively. He often introduced the names of speakers and sometimes speakers and addressees to facilitate reading and comprehension and supplied in the margin two verses that the text had omitted (75 and 126). Even

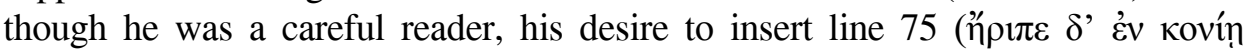

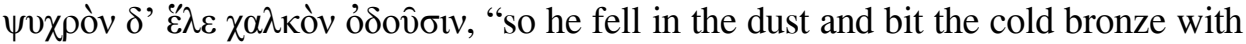
his teeth") between 83 and 84 , appears misguided. ${ }^{5}$ In that way a warrior who died because he had lost his hand in the Homeric text (82-83 "the arm all bloody fell to the ground and down over his eyes came dark death and strong fate") finds himself encountering a double death, biting in addition the cold bronze with his teeth. Corrections might have comic implications.

Originally the roll was very long and its owner must have valued it a great deal. Thus the desire of this second less capable hand to preserve the entirety of column one seems well justified. The beginnings of all the lines of this column, in fact, had broken away. Besides patching the papyrus with strips glued to the recto, the writer got a fresh piece of papyrus and glued it on the verso writing on it the beginnings of the lines that had fallen off and marking them off with a perpendicular line. He left a large blank space between what he restored and the existing formally written text as if he were conscious of how different his hand was.

Genetic criticism leaves some space to intentionality though this concept needs to be used with caution. At the moment of genesis, a writer elaborates a text in his mind, writes it down, and then may continue to revise. The various revisions of a text let us know that a writer's modifications were conscious and meaningful. The revision process, however, is not always linear but fluid and

\footnotetext{
${ }^{3}$ The text was joined with P.Köln V 210, see M-P ${ }^{3} 733$, LDAB 2026.

${ }^{4}$ P.Oxy. II 237.

${ }^{5}$ The writer added line 75 in the top margin and indicated with a sign where it should be added.
} 
continuous and the last version of a text may not be the one that a writer ultimately chooses. ${ }^{6}$ We are limited by the evidence that does not allow us to go beyond and especially so in the case of papyri which are affected by the chances of survival. Yet, there are some papyrological texts that show revisions at the authorial level with additions, corrections, and writings in the margins. In what follows I will offer my observations on some papyrological texts that exist in more than one versions, when writers penned different drafts that flowed from one to another. In these cases, the existence of more than one copy that was revised, cancellations, and insertions show how texts could be fluid and not definitive. Some of these texts represent new versions and others are just refinements of previous writings. I will take into account the dossier of Lollianos, the public grammarian of Oxyrhynchus, that contains drafts of a petition. I will later examine texts from the Archive of Ammon scholasticos of Panopolis and the drafts of a letter and a petition. I will return to individual autographs on papyrus that offer examples of revision below, when discussing the Anonymus Londinensis.

\section{The Dossier of Lollianos}

The dossier of Lollianos offers great material for observation. Peter Parsons in a masterful paper declared modestly: "Only ambiguous blossoms can be plucked in these thickets," but perhaps one can go beyond that and make some progress in reading the flowery language of Lollianos. ${ }^{7}$ Lollianos addressed a petition to the emperors in order to have his salary paid regularly, something that never happened before. He proposed therefore to obtain from the city an orchard that he could lease. The dossier consists of three texts, written in different hands, of which two are drafts of the same petition to the emperors Valerian and Gallienus (A and C) and one (B) is the draft of a letter to someone powerful at court who could endorse the petition. Parsons wondered if the first and second text were written by Lollianos himself in different hands. I agree with his supposition because people were able to write in different scripts depending on the occasion. The ability to master various writing styles is evident in the archive of Ammon that I will examine later. Serena Connolly has pointed to the fact that Lollianos' formulaic expressions regarding the emperors show a development because he used a basic formulation in the first draft which he updated in the second. ${ }^{8}$ This might confirm the impression that draft $\mathrm{C}$ was not written by Lollianos' himself

\footnotetext{
${ }^{6}$ See Gurd, Revision, 162. In addition, genetic critics do not focus particularly on a search for the best, most authentic version; all versions are part of the history of a text.

${ }^{7}$ Parsons, Petitions, 419. The dossier was later published in P.Oxy. XLVII 3366 in a shortened version.

${ }^{8}$ Connolly, Grammarian. This scholar examines the formulaic expressions in the course of five centuries.
} 
but by a professional, who knew current formulations. ${ }^{9}$

The differences between Lollianos' two drafts are striking in so far as they reveal that though he initially had in mind a grandiose encomium of the two emperors, he then (as the second draft shows) realized that some changes were necessary. In the first draft after addressing Valerian and Gallienus, Lollianos immediately introduced himself as public grammarian as if the emperors would recognize and value his position in the realm of education; he then continued (11. 6-13):

Your heavenly magnanimity which has irradiated your domain, the whole civilized world, and your familiarity with the Muses (for education sits besides you on the throne) have given me confidence to offer you a just and lawful petition, this one. Your deified ancestors fixed, in proportion to the size of the cities, a number of public grammatici...

With classic grandeur, he thus presented the emperors as the natural supporters of higher education. They had a "familiarity" (oikśı $\omega \sigma ı \varsigma)$ with the Muses, an affinity that would make them the ideal allies of a grammarian; the petition would appeal to them directly because of their learned upbringing. But were such majestic praises realistic?

Lollianos drafted a second text with a different tone. After the address to the emperor, he did not present himself as a grammarian but mentioned only his name. Did the emperors know who grammarians were?

Your heavenly magnanimity, great emperors, which has extended its benevolence to the whole of your domain, the civilized world, and sent it forth to every corner, has given me too confidence to offer your heavenly genius a petition closely connected with both reason and justice. Here it is. Your deified ancestors who have ruled at different times, rulers who have irradiated their domain, the world, in virtue and paideia fixed in proportion to the size of the cities a number of public grammarians... (C 11. 45-53)

Lollianos praised Valerian and Gallienus for their $\mu \varepsilon \gamma \alpha \lambda$ $\varphi \iota \lambda \alpha v \theta \rho \omega \pi^{\prime} \alpha$ and their care for reason and justice but declined any connection they might have with culture and education. In this second draft, the emperors lost their special friendship with the Muses. Only the ancestors of the current emperors did deserve to be remembered for their virtue and paideia. Why did Lollianos draft a text so different from the previous one? In this case, we may agree with Hershel Parker who argued that early versions are often better than later ones in so far as

\footnotetext{
${ }^{9}$ In a private communication Peter Parsons doubted that the hand of $\mathrm{C}$ could be Lollianos', but did not categorically excluded it. The different formulaic expressions used in this text seem a confirmation that someone else penned it.
} 
they preserve original authorial authenticity. ${ }^{10}$ The first version with its classical allusions must have come to Lollianos' mind spontaneously. Like many grammarians, he knew how to compose encomia and perhaps even taught this skill to students as usually happened where a school of rhetoric was not available. Menander Rhetor wrote a propos of the Basilikos logos:

You will speak of [the emperor's] paideia ... his love of learning, his quickness, his enthusiasm for study ... and say "in his education he stood out among his contemporaries". ${ }^{11}$

But in truth were Valerian and Gallienus preeminent for their love of the Muses? History did not point to this trait in their personality. The image we have of them is of men of arms. Lollianos must have realized that paideia was not their forte, while previous emperors, their deified ancestors, such as Hadrian, Antoninus Pius, or Marcus Aurelius were men of letters who deserved to be mentioned for their educational achievements. The second draft was more realistic and had more chances to be accepted.

\section{The Archive of Ammon of Panopolis}

The fourth-century Archive of papers of Ammon of Panopolis is of exceptional interest for several reasons. ${ }^{12}$ It concerns a family of local pagan priests in a period when Christianity was affirming itself elsewhere. It offers the background of literary texts in Greek and Coptic and testifies to the high levels of education from which emerged its famous poets. ${ }^{13}$ The family of Ammon belonged to the local aristocracy of the city and its male members were highly educated. Ammon's nephew Apollon was a poet and his brother Harpocration was a public sophist in Panopolis and a prose panegyrist and held some public offices. ${ }^{14}$ Ammon was a scholastikos, that is, an advocate, who had received some education in rhetoric and philosophy and styled himself as one of those that had received some education in rhetoric and philosophy. ${ }^{15}$ Among his papers was found a list of philosophers written in his more informal hand. ${ }^{16}$ This list of scholarchs contributes to highlight his educational attainments. He wrote it on a

\footnotetext{
${ }^{10}$ Parker, Flawed Texts. Later versions reflect localized changes that sometimes subvert a writer's original intention. Cf. Bryant, Fluid Text, 46-7.

${ }^{11}$ Russell/Wilson, Menander, treatise II, pp. 76-95, at p. 83.

${ }^{12}$ P.Ammon I and II.

${ }^{13}$ Cameron, Poets.

${ }^{14}$ Browne, Panegyric and Harpocration. Harpocration travelled with the court and served as imperial procurator and as curator civitatis, involved in the financial administration.

${ }^{15}$ P.Ammon II, p. 3.

${ }^{16}$ See P.Duke inv. 178, P. Ammon I 1. Willis Papyri, 145-51. Cf. also Willis/Dorandi, Lista.
} 
single piece of papyrus that originally contained three mutilated columns. The fact that he employed his rough and more informal hand confirms that he noted the various names for his own use. The list contains Presocratics, Academics, Cynics, Peripatetics, and Stoics in teacher-student sequence initially and then by schools. Since Ammon's note does not correspond to contemporary doxography, it probably represented his attempt to organize the knowledge that he had acquired or was acquiring in a school in Panopolis. It is impossible to date the papyrus with any precision so that it cannot be ruled out that Ammon wrote the list as an exercise. Even though the texts written by him show his educational achievements, there is no doubt that his brother was on a different level as an imperial panegyrist travelling with the court. In what follows I am going to consider (albeit briefly) the reworking of his very long letter to his mother and the various drafts of his petition to the katholikos of Egypt in order to suggest that his repeated 'improvements' at his prose might have been motivated by a desire to emulate and rival his famous brother. ${ }^{17}$

Like Lollianos, Ammon used two different hands in penning his texts. $\mathrm{He}$ valued writing to friends in his own hand, as he mentioned in the long letter to his mother (col. v line 25). ${ }^{18} \mathrm{He}$ wrote most of his drafts and the list of philosophers in a large informal hand but used a smaller and more regular script for writing that was destined to other people's eyes. Ammon chose his better hand to write to his mother a letter that was mainly supposed to reassure her in the difficult circumstances the family was encountering in his absence, since he had to stay in Alexandria for a couple of months. Peter van Minnen plausibly suggested that the corrections and insertions in the text prove that Ammon was copying from a draft but asked himself why did the scholastikos go through the trouble of reworking a private letter in such a careful way, even trying his hand at a draft. ${ }^{19}$ He suggested that Ammon was trying to impress his mother who would appreciate a text rhetorically wrought and replete with philosophical statements on the necessity to endure Fortune and with assurances that the cycle of Fortune would restore the family past prosperity. I think that this scenario is implausible. It is virtually certain that a woman in fourth-century Egypt would not have reached such a level of education. At the most, since she belonged to an unusually cultivated family she might have had some grammatical instruction in addition to training in a primary school..$^{20}$ The letter is a carefully written literary specimen and is different from other epistolary texts since it contained high and low dots, iota adscript, and marks of length, and was written in Attic Greek without the Koine forms to which Ammon's mother was habituated. In addition, if Ammon had expected his mother

\footnotetext{
${ }^{17}$ The Archive would need much more attention than I can devote to it in this occasion.

${ }^{18}$ P.Ammon I 3, pp. 19-46.

${ }^{19}$ Van Minnen, Letters, 188-9.

${ }^{20}$ Cf. Cribiore, Gymnastics, 74-101.
} 
to read the very long text on her own, presumably he would have used his informal large hand that had a higher degree of legibility.

The editors dated the letter to 348, the same year when Ammon wrote the many drafts of a petition to the katholikos of Egypt after Harpocration had died. It was recognized, however, that this date needs to be moved earlier to a time when the panegyrist was abroad and was expected to return home with great honor. ${ }^{21}$ Harpocration is present extensively in the letter. He had left instructions at his departure from Alexandria. He had the power to help a relative to the propheteia by relying on the emperor's good will. Ammon tells his mother that his brother was supposed to return home with great honor: "Fortune has again begun to raise him up, for he is dear to the eternal gods. And whenever everything abases him, he rises to moderate success and then he rises up again to greatness...and already he has returned to the imperial court...at that time I wished to hold him back but I couldn't". ${ }^{22}$ Ammon reports that his brother was a close friend of the hegemon of the Ethiopians and was helping him in appealing to the emperor. The family's fortune was at a risk but Harpocration was a protagonist in the events of the time. I suggest that Ammon's letter was destined to the panegyrist's eyes who would surely appreciate Ammon's brotherly devotion in reporting his achievements to their mother. Harpocration could easily read the small characters of the whole text and was able to value its rhetorical embellishments and philosophical disquisitions. Using modern terminology, one could say that Ammon in writing to his mother also cc'ed Harpocration who either received a duplicate of the letter before coming home or more likely was expected to read the letter once he returned.

The repeated drafts of a petition of Ammon of Panopolis to the katholikos of Egypt Flavius Sisinnius in AD 348 are also evidence of shifting intentions. After the recent death of his brother Harpocration, Ammon was embroiled in a litigation with a certain Eugenios concerning three female slaves. ${ }^{23} \mathrm{He}$ aimed at composing an effective petition that necessitated continuous revisions that are evidence of his growing uncertainty. The modern reader has the impression that Harpocration continues to die in front of his eyes or at least that Ammon's feelings for his demise are constantly renewed. By reviewing some of the changes we can attempt to highlight Ammon's habits as a literate person and his intentions. As we have seen, Ammon observed specific conventions in the writing that was supposed to reach immediately other people: a rather formal hand and the idiosyncratic distinction with a macron of the dative singular of the first declension from the nominative plural. ${ }^{24}$ An official text, however, could

\footnotetext{
${ }^{21}$ Bagnall, Egypt, 272-3; Van Minnen, Letters, 194-5.

${ }^{22}$ Col. iii.

${ }^{23}$ See P.Ammon I 7-15 and P.Ammon II 32-46. The latter volume republished most of the documents in light of new evidence from the Florence papyri.

${ }^{24}$ Besides the letter, other texts that observe this convention are P. Ammon II 27, 30, and the
} 
not be submitted if he found necessary to insert corrections ${ }^{25}$ or when he realized that the papyrus sheet was inadequate. His initial attempt at the petition further shows that he considered another requirement as a mark of formal writing, that is, placing the text in columns, a convention that he abandoned in the later drafts. ${ }^{26} \mathrm{He}$ had started to pen this text formally and with some determination but soon realized that it was impossible to finish the definitive text at the moment and switched to a less controlled hand. Free from stricter conditions, he then inserted some text and added more in the margins. We can further perceive Ammon's impatience in shaping over and over his petition by his frequent penning a papyrus transversa charta, that is by turning it 90 degrees. ${ }^{27}$ It appears that he did that for taking advantage of a smoother surface by writing along the fibers and for using the sheet in all its horizontal length.

At the beginning of 38, which he had meant to be a conclusive copy, with self-conscious pride he introduced immediately the phrase, "I myself know that a quiet life free from business befits those educated in philosophy and rhetoric." In the next long draft, ${ }^{28}$ he omitted the expression that identified him as an unusually educated man. At this point he tried his hand for the first time at the formal proem of many lines that will remain in the later most complete version. It is possible that he felt that the rhetorical proem was sufficient evidence of his education and did not want to tire his addressee further. In the last version, however, both the proud allusion to himself and the long proem stand side by side. ${ }^{29}$ What are the ingredients of this preamble?

My lord throughout that time I was filled with true happiness ... while the goodwill of the gods together with Agathos Daimon was guiding the land of the Upper Egyptians and all the rest of mankind we were considered to be blessed and enviable because of such good fortune like unto which neither before did that province have nor hereafter may expect to behold another such kindly guardian. Now the inhabitants of the most splendid city are successors to that prosperity of ours, but I myself too reckon that at present I have again come into a share of good fortune since it has been allotted to me too that I appear in court pleading my case before so great a magistrate and judge, whose unmatched judgment among diverse peoples both hitherto and now

\footnotetext{
initial lines of 38 .

${ }^{25}$ As it happens in P.Ammon II 6, which became another frustrated attempt.

${ }^{26}$ P.Ammon II 38 (P.Ammon I 7).

${ }^{27}$ Cf. P.Ammon II 39, 40, 43, 45, and 46.

${ }^{28}$ P.Ammon II 37.

${ }^{29}$ I am considering now P.Ammon II 41 the most compete text and will follow the translation in P.Ammon I 13,9-10, p. 136. The editors of P.Ammon II ventured that text 45 might be the last surviving version of the petition but it lacks the beginning and therefore does not contain an eventual preamble.
} 
experience has shown. I myself, to be sure, know that a quiet life free from business befits those educated in philosophy and rhetoric.

In a nutshell these were the ingredients of panegyrics for governors. Prosphonetikoi, addresses to governors, did not include all the elements of speeches of praise. ${ }^{30}$ Willis considered the style of the writing not appropriate for a petition and used words such as "unabashedly flattering". ${ }^{31}$

Was Ammon the scholastikos trying his hand at something that was the specialty of his formidable brother? He described Harpocration as

moving much time from land to land, from Greece to Rome and from Rome to Constantinople and from one country to the other, traversing virtually through most parts of the earth, he did not cease proclaiming the victories of our gloriously triumphant emperors and delivering royal orations everywhere. ${ }^{32}$

Harpocration had died not long ago and the preamble of the final draft of the petition was worthy of him.

\section{A Papyrus of Favorinus: Pap. Vat. Gr. 11 verso}

The papyrus of Favorinus, Vaticanus Graecus 11 is an opistographic roll that contains in the verso his Пєрі Фvүîৎ, On Exile, and should be dated to the half of the third century. ${ }^{33}$ In the recto two different scribes wrote a documentary text, P.Marm. ${ }^{34}$ A single scribe copied the text of Favorinus in a hand that is easily readable but not calligraphic. ${ }^{35}$ The text was probably a private copy. The

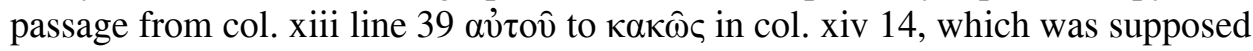
to appear later, was copied incorrectly at that place; the writer then continued to copy the speech in sequence (in sections xvi 2 and xvi 3) and added again, this time at the right place (xvi 4 and xvi 5), the passage wrongly written previously.

I am not surprised that Adele Tepedino Guerra did not transcribe the sections that the writer wrote by mistake since unfortunately this is the standard way to treat different versions that in the best of cases are confined to the apparatus. In her edition the apparatus contains only the beginning and ending words of the cancelled version even though the two wrongly transcribed passages differ on

\footnotetext{
${ }^{30}$ Russell/Wilson, Menander, 165-71.

${ }^{31}$ P.Ammon I, p. 116.

${ }^{32}$ Variations on the subject: P.Ammon II 37,10-12; 39,23 and b1-b6; 41,24-25; 45,6-8.

${ }^{33}$ M-P $\mathrm{P}^{3} 455$, LDAB 1065. It was edited by Norsa/Vitelli, Papiro Vaticano, 17-32 together with reproductions.

${ }^{34}$ See Ricciardetto, Documents.

${ }^{35}$ Tepedino Guerra, Esilio, 27-30. For a good description of the papyrus, see Bastianini, Favorino.
} 
account of several phonetic mistakes and two variants. ${ }^{36}$ Editorial conventions, however, are changing nowadays so that a text that is to be seen in its fluidity needs to be fully documented. The scribe of Favorinus was confused in reading and transcribing by memory the text so that he omitted a longer passage of about 20 lines (col. xvi from line 26) and relocated it in col. xviii. He indicated his mistake and the rearrangement of the lines by various signs that he used freely and not completely appropriately. He did not follow the current and traditional usage of these lectional signs but employed them with the sole aim of giving some indications to his readers. As Kathleen McNamee has argued recently, in later antiquity many signs were employed in an utilitarian way to organize or decorate a text. ${ }^{37}$ After noticing the mistakenly transcribed passage in col. xiii and xiv, this scribe surrounded the incorrect text with lines that are very similar (as we will see) to those appearing in the Anonymus, in order to signal that the text needed to be canceled and had to be moved in a different part. ${ }^{38}$

It is worthwhile to try to explore the origin of this unusual convention. Sequestering an incorrect text by encircling it with lines does not usually occur in literary texts but is a documentary practice used in registers and accounts. ${ }^{39}$ In a register from Hermopolis dated to the first or second century AD, PSI XVI 1621, the same kind of parenthesis defines lines 2-3 and 6-9 in the first column. The editor supposed that these lines had to be moved to a different parts of the register or to a different register all together. A similar convention is observed in P.Mil. I $2,27 .^{40}$ We can venture that the scribe who penned Vaticanus Graecus 11 was familiar with documents and perhaps engaged in writing these texts too. His hand in the text of Favorinus is clear and capable but is not markedly a book hand with literary pretensions. Scribes could certainly master different kinds of hands and it has been shown that they were professionally trained to write different kinds of texts. ${ }^{41}$ What is unusual here is the considerable trouble this writer experienced in copying the text. Are we confronting a case of someone with visual problems? Did the writer suffer from some form of dyslexia and found it difficult to keep up with the pace of the text in reading it? Was the model in a state of disarray? Or perhaps it was only writing fatigue. This scribe may echo the exhausted writer of a papyrus

\footnotetext{
${ }^{36}$ Tepedino Guerra, Esilio, 29-30.

${ }^{37}$ See McNamee, Papyri.

${ }^{38} \mathrm{He}$ also marked the version to be discarded with an initial and a final $\chi$, see McNamee, Sigla, 19. Cf. also Nocchi Macedo, Signes, 38-9. I thank Gabriel Nocchi Macedo for sending me PDF images of the papyrus.

${ }^{39}$ A. Ricciardetto has kindly indicated to me a poetic text where 7 verses were preceded by a long line in the left margin. Since the papyrus is mutilated on the right, it is impossible to know if another line was present in the left margin. See Perale, Esametri, 74 n. 7.

${ }^{40}$ See the plate in Montevecchi, Papirologia, 33 plate 19. I thank Guido Bastianini for indicating these papyri to me.

${ }^{41}$ See Mugridge, Stages.
} 
of Menander who added after the end title: "Don't laugh at the writing ... how glad I am to rest my three fingers!" ${ }^{42}$

\section{Autograph Texts on Papyrus}

Daniela Manetti has shown that the Anonymus Londinensis, a medical text, is an autograph in which the writer did not copy from a model but showed the process of his thinking, his doubts, and his revisions ${ }^{43}$ Before making some observations on the two drafts of a passage in this text, I would like to focus on other autographs on papyrus. It might be useful to clarify when a text can be regarded as an autograph. Numerous school exercises, for example, were written by the students themselves but cannot be considered proper 'autographs' when students might have been copying from a model and their texts do not include alterations. ${ }^{44}$ Genetic criticism values textual revisions both when drafts of some texts are extant or when single texts elucidate how a writer positioned himself versus his writing by trying to sharpen and 'improve' on his expressions. In this way it is possible to glimpse at the motives behind each revision sequence. Autographs on papyrus are not very numerous. Manetti mentioned two lists of autographs compiled respectively by Tiziano Dorandi and by Maryline Parca ${ }^{45}$ Since the last of these lists dates to 1991 and no further attention was paid to this issue, it is worthwhile to reconsider the evidence with a few observations. ${ }^{46}$

A text that shows revisions is P.Lond.Lit. 51, a monody from the second century $\mathrm{AD}$, which has attracted limited attention. ${ }^{47}$ This piece is a tortuous composition probably of an aspiring poet but is certainly not the text that a young student jotted down from memory. The last scholar who devoted attention to this poetic text was E. Gangutia Elicegui who considered it a school exercise in which a desastrado alumno was forced to copy the verses by his whipyielding teacher who had composed this pedantic poem. ${ }^{48}$ This papyrus is not a

\footnotetext{
${ }^{42}$ P.Sorb. inv. 2272b, plate 40 in Turner, GMAW.

${ }^{43}$ Manetti, Autografi; Ead., Doxography, 129-35; Ead., Presence. See M-P 2339 with full bibliography. Recent editions of this text are by Manetti, Anonymi; Ricciardetto, Anonyme, with very useful plates; Ricciardetto, Anonyme de Londres.

${ }^{44}$ Consider for example a rhetorical exercise, P.Oxy. XVII 2084. A student with an unprofessional hand penned an encomium of the fig and inserted the title in a very amateurish frame. It is likely that he composed the text but this is not entirely certain and therefore it cannot be regarded as a proper 'autograph'.

${ }^{45}$ Dorandi, Autoren; cf. also Dorandi, Stylet, 53-60, and Officina, 48-51; Parca, Ptocheia, 3 n. 7.

${ }^{46}$ Some texts were overlooked in the past and others were published after 1991 . Only a very accurate perusal of all the papyri could further determine if there are more autographs among them.

${ }^{47}$ See M-P 1922 with bibliography, LDAB 4729.

${ }^{48}$ Gangutia Elicegui, Notas argued cleverly that the first lines of the poetic text refer to Memnon, the Ethiopian king who brought his army to Troy, was fighting on the Trojan side, and
} 
copy of a previous text or an exercise from memory. Scholars who considered it a poor school exercise insisted on the rough and uncouth aspect of the hand that was appropriate to a text they found incomprehensible. One must be more forgiving. The material conditions of the text, which is written across the fibers and is not well preserved, and the continuous rewriting do not facilitate understanding. The hand is a private fluent hand, mostly cursive and belonged to someone who had been exposed to much writing. There are many clumsy erasures, stains, corrections, and verses rewritten above the line. The script shows letters of various size, some of which are very large like the repeated word teknon, "son". 49 It seems that the writer meant to emphasize the theme of this composition, a lament of a mother for her son. The writer was dealing with a poem that resisted improvements and had trouble finding the right words to fit the anapests. Some comparisons are inappropriate for the theme he was developing. ${ }^{50}$

P.Lond.Lit. 138 is also in my view an autograph. ${ }^{51}$ It is dated to the first century and is written on the verso of a tomos synkollesimos that contains in the recto an epigram and documents from AD 5-15. The long text with at least 10 columns contains plenty of corrections and didactic notes and consists of six rhetorical exercises, progymnasmata and declamations. The small hand with abbreviations would be consistent with the view that a teacher of rhetoric compiled the collection for his use or for his class. Giuseppe Russo, who republished the second exercise, a declamation, reports the opinion of Milne in the original publication, who regarded the papyrus as an autograph. Russo also suggests the possibility that a scribe put together a collection introducing corrections from previous material, a suggestion that seems to me very unlikely. ${ }^{52}$

Autograph texts are often found among rhetorical exercises that might not be copied from models (as in previous stages of education) but were composed by more proficient students who had rather accomplished hands. Two papyri in P.Oxy. XLV, 3235 and 3236, both written on the versos, appear written by the respective authors. They are meletai written in the persona of Demosthenes and contain corrections and additions that do not look like the work of scribes but seems textual revisions. The hands of both are in a severe style that shows some irregularities and is compatible with the hypothesis that the authors (and not professionals) penned them.

ended up killed by Achilles. Lines 9-10 and 25-26 present the falling of Phaethon in the Eridanus river when he could not control the powerful horses of the Sun's chariot.

${ }^{49}$ Lines 4 and 23.

${ }^{50}$ Since Eos is a mother anticipating her son's demise the mention of Cybele and Aphrodite and their disastrous wedlock is not much to the point. Searching for more suitable comparisons without finding any, the confused writer inserted the name Adonis in the interlinear after line 16.

${ }^{51}$ See M-P 2515 ; LDAB 4325.

${ }^{52}$ Russo Declamazione, 302 . The opinion that the text is an autograph is implicitly corroborated by Stramaglia, Temi, 167. 
Another text written on the verso that contains a rhetorical exercise is P.Oxy. LXVIII 4647. It is an encomium of the horse that shows corrections and additions by the same hand. It is certainly an autograph exercise. The student who composed it with an irregular, cramped hand had problems with orthography. P.Oxy. LXXVI 5093 is a more ambitious text that was probably used for teaching. It consists of an opisthograph roll with rhetorical epideixeis, which is written in an informal handwriting of the type used in commentaries.$^{53}$ It shows corrections by the same hand and it should represent the writer's own notes. ${ }^{54}$

\section{Two Textual Versions in the Anonymus Londinensis}

The text of the Anonymus Londinensis (P.Lond.Lit. 165) that expert scholars are discussing in this volume is certainly an autograph. The hand could be compared with those found in commentaries and is a bit informal. The letters touch or sometimes show ligatures that do not affect letter shapes. The script is slightly inclined to the right mostly because of the speed of writing. The characteristics of the handwriting, in any case, do not point especially to its nature as an autograph but alterations and improvements clarify that the text was not static but was fluid. The text consists of thirty-nine columns of writing. The corrections of individual mistakes are not numerous but there are more significant alterations. The writer wrote numerous notes on top of the line or in the margin, of which some are simple corrections and others, the most noteworthy, complete or enrich the argument, introduce new details or summarize what was said before. In addition, col. i and ii contain two different versions of a similar text. The beginning of the first column is missing but what remains shows that it was concerned with the meaning of diathesis "disposition" and specifically of pathos ("passion", "experience", or "condition"), with a distinction of pathos of the body and of the soul. The two drafts follow each other in col. i and ii. One version starts in col. i line 15 and continues to 38. The second version, the better one in the eyes of the writer and the one he intended to keep, is longer and includes col. i 39 to col. ii 17 (see image below). With some repetitions and overlapping, the two texts are different. The first is not as argumentative as the second; it looks like a summary of arguments, notes perhaps as an aid memoire. When the writer, for example, offers a designation of the soul according to the three philosophical schools in a kind of list, he ends up discarding the peripatetic definition in an abrupt way. The second version is richer and more coherent and diverges from the first in a few things.

The first version is defined by a long vertical line in the right margin that

\footnotetext{
${ }^{53}$ See above the hand B of Lollianos and P.Lond.Lit. 138.

${ }^{54}$ As Daniela Colomo remarks, it cannot be positively excluded that the writer made a collection of excerpta but the hypothesis of an autograph is more consistent with the evidence.
} 
starts from the end of 16 down to 39 and is then connected to a horizontal line that occupies all 39. The draft that the writer sequesters in this way is thus surrounded by one vertical line and a horizontal one. On the analogy with the papyrus of Favorinus, I strongly suspect that the text was marked off by another vertical line in the left margin. The line beginnings in col. $i$ of the papyrus had fallen off and, if another line existed in the margin, it fell off with the rest. The example of the Vatican papyrus shows that the writing to be deleted or moved was surrounded by lines on many sides, in a kind of 'caging.'

This is not the first time that an ancient text includes different versions of a passage even though caution is needed in identifying them. ${ }^{55} \mathrm{I}$ will examine briefly only a few cases in the hope that they might suggest something about the origin of the versions of the Anonymus. More texts of this kind exist and I am currently involved in identifying and studying them. ${ }^{56}$ The oldest of these texts is Plato's Cratylus. In the most recent edition (1995) of this dialogue in the Oxford Classical Texts, the editors present one after the other two different versions which were both transmitted by the medieval codices. ${ }^{57}$ This editorial presentation changes the conventional layout of the text by incorporating variants into it, like many decades before Von Arnim had done with Dio. It is in agreement with modern German conventions where the apparatus becomes part of the reading page. ${ }^{58}$ The first version of the Cratylus, called A, traditionally was considered an interpolation and includes $437 \mathrm{~d} 10$ to $438 \mathrm{a} 2 \mathrm{e}$, while the second comprises 438a3-b3. Scholars have formulated different hypotheses to try to explain version A. ${ }^{59}$ For some of them A should be attributed to Plato himself who was dissatisfied with the one version of the passage, reworked it, and produced a different one. Since he had some doubts on the validity of one or the other version, was concerned for the diversity of his readers and wanted to expose them to both variants he left them in place. David Sedley, who accepted both variants as authentic, however, pointed to an interesting editorial process by which a contemporary of Plato copied some variants in the margins of his copy of the Cratylus and those crept into the text. ${ }^{60}$

Another case is Oration 11, the Trojan Oration of Dio Chrysostom, which contains two versions of sections 22-24. I agree with Von Arnim that these are not later interpolations but ancient 'interpolations' if we want to use such term.

${ }^{55}$ Let us remember the words of Pasquali, Tradizione, 397: "Ci troviamo talora di fronte a un resticciolo di varianti che deve risalire all'autore stesso". Cf. Dorandi, Officina, 123-39.

${ }^{56}$ Since these versions are not on papyrus, I do not want to insist on them.

${ }^{57}$ Duke/Hicken/Nicoll/Robinson/Strachan, Opera. Version A is attested only in ms. W.

${ }^{58}$ Gabler, Criticism. Cf. Contini, Breviario, 7-8.

${ }^{59}$ See Carlini, Platone; Valenti, Variante; Sedley, Cratylus; Ademollo, Cratylus, Appendix 1, pp. 489-95 summarizes the question. Ademollo recognizes that certainty does not exist but the argument that Version A is an author's variant cannot be disproved.

${ }^{60}$ Sedley, Cratylus, 9-10. 
As Dio says a few times, not only did he deliver orations everywhere but some of his speeches circulated in different provinces (by his students perhaps) and came back somewhat modified because people introduced variants. Dio may have memorized a speech and when he delivered to various audiences some modifications crept in. The editor who put together his orations might have found notes from different texts and included them. The Trojan Oration, moreover, circulated in sophistic circles because of its educational message and students memorized parts and took down some passages that were not always faithful to the original.

Another example of a text containing a double version is a dialogue of Lucian Icaromenippus. In this case, however, section 15 shows two different versions that are enmeshed with one another. In an article, Heinz-Günter Nesselrath pointed to the overlapping of phrases and repetitions arguing that both texts come from Lucian. I disagree with the possibility that Lucian took care personally of the corpus of his dialogues and revised them before publishing them because I think he would have noticed the discrepancy. Like Dio, Lucian was a travelling sophist: he might have introduced modifications as he delivered a piece again or people in the audience did when they took one down.

Time constraints do not allow me to go through other doublets that are visible in Plotinus, Libanius, or in the Or. 42 of Gregory of Nazianzus. Some texts or parts of texts in antiquity circulated in different forms when an author adapted something to a specific audience or distributed a text to friends and students before editing it. Audiences that were present at lectures were free to alter those texts and even to publish them under their own names.

The Anon. probably wrote one version, returned to the text, was not satisfied, and wrote the other version. Even though the text appears to be an autograph on which he worked actively, he did not write in a vacuum as Daniela Manetti pointed out and his text bears traces of others' writings. ${ }^{61}$ The first and/or the second version may represent memories of a text he read or of lectures he heard. The first draft reads like an ensemble of notes. He then enriched the text and produced the second version that he decided to keep. In another scenario, if the Anon. is the author of the two versions entirely, we possibly may think of the Cratylus. He wrote one text, was dissatisfied of its simplicity and rewrote the passage entirely.

Lastly, a plea for students. Hermann Diels was certainly wrong in regarding the Anon. as a text copied by an ignorant and unskilled student, and yet some caution is necessary. Even though the word 'student' usually evokes amateurish and deficient work, some students were exceedingly competent. How about those papyri from Herculaneum written in hands far from elegant and reproduc-

\footnotetext{
${ }^{61}$ Manetti, Presence.
} 


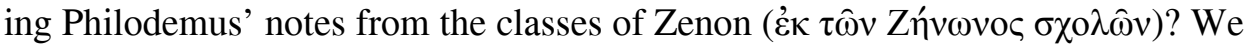
may also think of those pupils of teachers of philosophy in the Aristotelian and Platonist schools who wrote notes $\dot{\alpha} \pi$ ò $\varphi \omega v \eta \hat{~} \varsigma$, from the living voice of their teachers, and produced various, differing, and competent written records. We do not have proofs, yet we cannot exclude that the Anon. was like one of them.

\section{Conclusion}

I have closely inspected a few literary papyri in the hope that my observations might reveal something more precise about their nature. Genetic criticism helps us view texts not as static and definitive pieces of writing but suggests new ways of reading and interpreting them. It brings to the fore aspects that have not attracted much attention. I have considered the interior and exterior characteristics of these, especially from the point of view of their authors. The texts have opened up to a degree disclosing why their writers have adopted certain conventions, have employed different scripts depending on the circumstances, and have revised them, introducing new words and phrases and composing alternate versions. All this may have shed some light into their creative process and shifting intentions in writing them down.

\section{Bibliography}

Ademollo, Cratylus = Francesco Ademollo, The Cratylus of Plato: A Commentary, Cambridge 2011. Bagnall, Egypt = Roger S. Bagnall Egypt in Late Antiquity, Princeton 1993.

Bastianini, Favorino = Guido Bastianini, "C.A. Ciampi, Favorino d'Arelate e la consolazione Пepì Фvүîৎ", in: F. Montanari et al. (eds.), Tesi di Laurea di C.A. Ciampi, Pisa 1940/41, Pisa 2011, 1-5.

Browne, Panegyric = Gerald M. G. M. Browne, A Panegyric from Panopolis, in: Proceedings of the XIV International Congress of Papyrologists, London 1975, 29-33.

Browne, Harpocration = Gerald M. G. M. Browne, Harpocration Panegyrista, "Illinois Classical Studies" 2 (1977), 184-96.

Bryant, Fluid Text = John Bryant, The Fluid Text: A Theory of Revision and Editing for Book and Screen, Ann Arbor 2002.

Cameron, Poets = Alan E. Cameron, Wandering Poets: A Literary Movement in Byzantine Egypt, "Historia" 14 (1965), 470-509.

Carlini, Platone = Antonio Carlini, Il nuovo Platone di Oxford, "Rivista di Filologia e Istruzione Classica" 124 (1996), 366-75.

Connolly, Grammarian = Serena Connolly, A Grammarian Honors the Emperors, "Ancient History Bulletin" 24 (2010), 111-23.

Contini, Breviario = Gianfranco Contini, Breviario di ecdotica, Milano 1986.

Cribiore, Gymnastics = Raffaella Cribiore, Gymnastics of the Mind: Greek Education in Hellenistic and Roman Egypt, Princeton 2001.

Dorandi, Autoren $=$ Tiziano Dorandi, Den Autoren die Schulter geschaut: Arbeitsweise und Autographie bei den antiken Schriftellern, ZPE 87 (1991), 11-33. 
Dorandi, Stylet $=$ Tiziano Dorandi, Le stylet et la tablette. Dans le secret des auteurs antiques, Paris 2000.

Dorandi, Officina = Tiziano Dorandi, Nell'officina dei classici. Come lavoravano gli autori antichi, Roma 2007.

Duke/Hicken/Nicoll/Robinson/Strachan, Opera = E. A. Duke / W. F. Hicken / W. S. M. Nicoll / D. B. Robinson / J. C. G. Strachan (eds.), Platonis Opera I, Oxford 1995.

Gabler, Criticism = Hans Walter Gabler, Textual Criticism and Theory in Modern German Editing, in: H. W. Gabler / G. Bornstein / J. Bornan Pierce (eds.), Contemporary German Editorial Theory, Ann Arbor 1995, 1-16.

Gangutia Elicegui, Notas = Elvira Gangutia Elicegui, Notas interpretativas y paralelos a P.Lit.Lond. 51 (Cantus Lugubris 10 Heitsch, Fragmenta mimorum papyracea, Appendix 8 Cunningham, in: Miscelânea em honra da Doutora Maria Helena Rocha Pereira = "Humanitas" 47/1 (1995), 481-7.

Gurd, Work = Sean A. Gurd, Work in Progress: Literary Revision as Social Performance in Ancient Rome, Oxford 2012.

Gurd, Revision = Sean A. Gurd, Revision in Greek Literary Papyri, in: V. Wohl (ed.), Probabilities, Hypotheticals, and Counterfactuals in Ancient Greek Thought, New York 2014, 160-84.

Hay, Critique = Louis Hay, Qu'est-ce que la critique génétique?, ITEM, URL: <http://www.item. ens.fr/index.php?id=384032\#ftn1>.

Manetti, Autografi = Daniela Manetti, Autografi e incompiuti: Il caso dell'Anonimo Londinese, P.Lit.Lond 165, ZPE 100 (1994), 47-58.

Manetti, Doxography = Daniela Manetti, The Role of Doxography in the Anonymus Londiniensis, in: Ph. J. van der Eijk (ed.), Ancient Histories of Medicine. Essays in Medical Doxography and Historiography in Classical Antiquity, Leiden/Boston 1999, 94-141.

Manetti, Anonymi = Daniela Manetti, Anonymi Londiniensis, De medicina, Berlin 2011.

Manetti, Presence $=$ Daniela Manetti, Levels of Authorial Presence in Anonymus Londiniensis (P.Brit.Libr. inv. 137), "Trends in Classics" 5/1 (2013), 159-78.

McNamee, Sigla = Kathleen McNamee, Sigla and Select Marginalia in Greek Literary Papyri, Bruxelles 1992.

McNamee, Papyri = Kathleen McNamee, Sigla in Late Literary Papyri, in: G. Nocchi Macedo / M. C. Scappaticcio, Signes dans les textes, textes sur les signes, Liège 2017, 127-42.

Martelli, Ovid = Francesca Martelli, Ovid's Revisions: The editor as Author, Cambridge 2013.

Montevecchi, Papirologia = Orsolina Montevecchi, La papirologia, Milano 1988.

Mugridge, Stages = Alan Mugridge, Stages of Development in Scribal Professionalism in Early Christian Circles, PhD Diss., University of New England, 2010.

Neefs, Prévision = Jacques Neefs, La prévision de l'oeuvre, ITEM, URL: <http://www. item.ens.fr/index.php?id=173010>.

Nocchi Macedo, Signes $=$ Gabriel Nocchi Macedo, Signes et corrections dans le P.Vat.gr. $11^{v}$, in : E. Amato / M.-H Marganne (eds.), Le traité sur l' exil de Favorinos d'Arles. Papyrologie, philologie et literature, Rennes 2015, 31-47.

Norsa/Vitelli, Papiro Vaticano = Medea Norsa / Girolamo Vitelli, Il papiro Vaticano Greco, Città del Vaticano 1931.

Parca, Ptocheia = Maryline G. Parca, Ptocheia or Odysseus in Disguise at Troy (P. Köln VI 245), Atlanta (GA) 1991.

Parker, Flawed Texts $=$ Hershel Parker, Flawed Texts and Verbal Icons: Literary Authority in American Fiction, Evanston (IL) 1984.

Parsons, Petitions $=$ Peter J. Parsons Petitions and a Letter: The Grammarian's Complaint, in: A.

E. Hanson (ed.), Collectanea Papyrologica (P.Coll. Youtie), Bonn 1976, 409-46,

Pasquali, Tradizione = Giorgio Pasquali, Storia della tradizione e critica del testo, Firenze 1952. 
Perale, Esametri = Marco Perale, Esametri adespoti dalla Papyrussamlung di Vienna, "Tyche" 25 (2010), 73-80.

Ricciardetto, Anonyme = Antonio Ricciardetto (ed.), L'Anonyme de Londres (P.Lit.Lond. 165, Brit.Libr. inv. 137). Edition et traduction d'un papyrus médical grec du Ier siècle, Liège 2014.

Ricciardetto, Anonyme de Londres = Antonio Ricciardetto (ed.), L'Anonyme de Londres (P.Lit.Lond. 165, Brit.Libr. inv. 137) Un papyrus médicale grec du Ier siècle après J.-C., Paris 2016.

Ricciardetto, Documents = Antonio Ricciardetto, Les documents administratifs du recto du P.Vat.gr. 11, in : E. Amato / M.-H Marganne (eds.), Le traité sur l'exil de Favorinos d'Arles. Papyrologie, philologie et littérature, Rennes 2015, 49-64.

Russell/Wilson, Menander = D. A. Russell / N. G. Wilson, Menander Rhetor. A Commentary, Oxford 1981.

Russo, Declamazione $=$ Giuseppe Russo, L'uomo che rubò a se stesso. Una declamazione con notazioni didattiche (P.Lond.Lit. 138, coll. III 5-IV 18), APF 59 (2013), 301-25.

Sedley, Cratylus = David Sedley, Plato's Cratylus, Cambridge 2003.

Stramaglia, Temi $=$ Antonio Stramaglia, Temi 'sommersi' e trasmissione dei testi nella declamazione antica (con un regesto di papiri declamatori), in: L. Del Corso / F. De Vivo / A. Stramaglia (eds.), Nel segno del testo, edizioni, materiali e studi per Oronzo Pecere, Firenze 2015, 147-78.

Tepedino Guerra, Esilio = Adele Tepedino Guerra, Favorino di Arelate: L'Esilio (Pap.Vat. Gr. 11 verso), Roma 2007.

Turner, GMAW = Eric G. Turner, Greek Manuscripts of the Ancient World, ed. P. J. Parsons, London $1987^{2}$.

Valenti, Variante $=$ Veronica Valenti, Una variante d'autore: Plat. 'Crat.' 437D10-438A2, "Studi Classici e Orientali" 46 (1998), 769-831.

Van Minnen, Letters $=$ Peter van Minnen, The Letters and Other Papers of Ammon: Panopolis in the Fourth Century, in: A. Egberts / B. P. Muhs / J. van der Vliet (eds.), Perspectives on Panopolis: An Egyptian town from Alexander the Great to the Arab Conquest, Leiden 2002, 177-99.

Willis, Papyri = William H. Willis, Two Literary Papyri in an Archive from Panopolis, "Illinois Classical Studies" 3 (1978), 140-53.

Willis/Dorandi, Lista $=$ William H. Willis / Tiziano Dorandi, Lista di scolarchi, in: Corpus dei Papyri Filosofici I 1, Firenze 1989, 81-4. 


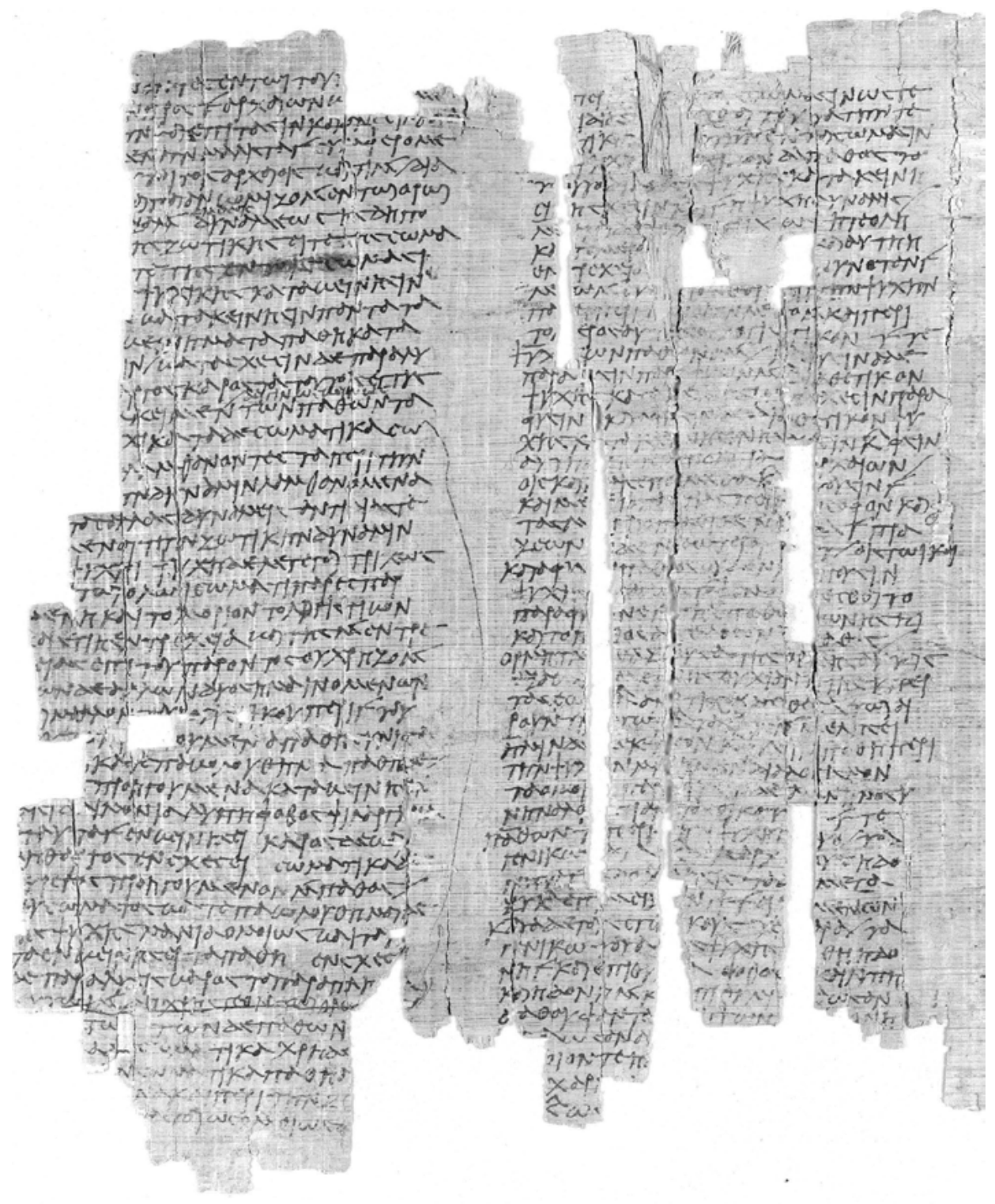

(C) British Library Board, BL inv. 137 = P.Lond.Lit. 165. 
